\title{
Autism spectrum disorder model mice: Focus on copy number variation and epigenetics
}

\author{
Nobuhiro NAKAI ${ }^{1,2,3}$, Susumu OTSUKA ${ }^{1}$, Jihwan MYUNG ${ }^{1,3}$ \& Toru TAKUMI ${ }^{1,3,4^{*}}$ \\ ${ }^{1}$ Graduate School of Biomedical Sciences, Hiroshima University, Hiroshima 734-8553, Japan; \\ ${ }^{2}$ Graduate School of Biostudies, Kyoto University, Kyoto 606-8501, Japan; \\ ${ }^{3}$ RIKEN Brain Science Institute, Wako 351-0198, Japan; \\ ${ }^{4}$ Core Research for Evolutional Science and Technology, Japan Science and Technology Agency, Tokyo 102-0076, Japan
}

\begin{abstract}
Autism spectrum disorder (ASD) is gathering concerns in socially developed countries. ASD is a neuropsychiatric disorder of genetic origin with high prevalence of $1 \%-2 \%$. The patients with ASD characteristically show impaired social skills. Today, many genetic studies identify numerous susceptible genes and genetic loci associated with ASD. Although some genetic factors can lead to abnormal brain function linked to ASD phenotypes, the pathogenic mechanism of ASD is still unclear. Here, we discuss a new mouse model for ASD as an advanced tool to understand the mechanism of ASD.
\end{abstract}

copy number variations, DNA methylation, histone modification, ASD model mouse

Citation: $\quad$ Nakai N, Otsuka S, Myung J, Takumi T. Autism spectrum disorder model mice: focus on copy number variation and epigenetics. Sci China Life Sci, 2015, 58: 976-984, doi: 10.1007/s11427-015-4891-7

Autism spectrum disorder (ASD) is diagnosed based on behavioral phenotypes usually by the age of three. The ASD patients show three major phenotypes: deficits in social interaction, impaired communication, and repetitive behavior or restricted interest. In the past two decades, the prevalence has greatly increased from $0.01 \%-0.02 \%$ to $1 \%-2.6 \%$ [1]; but even now, the cause is unknown. Through twin studies, ASD has been recognized as a disorder with genetic etiology. Monozygotic twins (MZ) show over $90 \%$ concordance of ASD, while dizygotic twins (DZ) show less than $10 \%$. Because genomic information of $\mathrm{MZ}$ completely coincides with each other while the coincidence is only $50 \%$ in DZ, the high concordance of ASD must have a genetic origin. Recently, a number of genetic variations in ASD patients were found by cytogenetics and genomics studies (Figure 1) [2-14]. The genetic variations include single nucleotide variations (SNVs) and copy number variations (CNVs). In the case of $\mathrm{SNV}$, the mutation causes severe functional loss of the

*Corresponding author (email: toru.takumi@ riken.jp) genes. CNV, on the other hand, is a large nucleotide change in chromosomal complement and can affect dosage of gene function in various ways (e.g. deletion or duplication). As it stands now, SNV and CNV are responsible for 5\%-7\% and $10 \%-20 \%$ of all ASD cases, respectively, while other causes of genetic variation remain unknown. A higher rate of $\mathrm{CNV}$ mutation is consistent within psychiatric disorders including schizophrenia. Incidentally, it is found that a greater enrichment of CNVs in individuals diagnosed with intellectual disability (ID) have severe craniofacial anomalies and cardiovascular defects compared to those with epilepsy or ASD [15]. CNVs in ASD can have comparatively milder effect than diseases with lethal pathology. In SNV cases, many of the causative genes identified code for cell adhesion molecules or scaffolding proteins (NLGN3, NLGN4, NRXN1, CNTNAP2, and SHANK3) [16]. These genes are important for organization of synaptic connections, which play a fundamental role in neuronal function. Not a few psychiatric syndromes show features of ASD. 


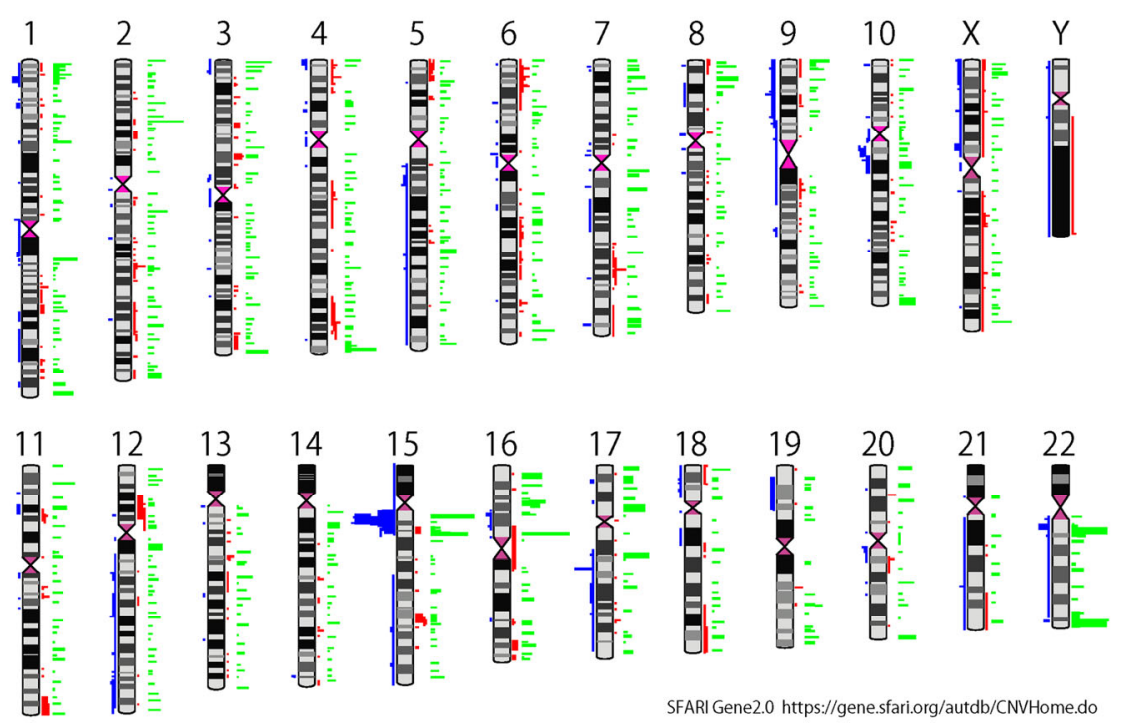

Figure 1 The chromosomal region of CNVs found in ASD. The positional information of CNVs derives from the database of SFARI (Simons Foundation Autism Research Initiative) Gene. Red, blue, and green indicate deletion, duplication, and deletion/duplication, respectively; the height of the sideling bar indicates the amount of information by the number of reports.

The patients with Rett syndrome (RTT) and Fragile X syndrome (FXS), which are neurodevelopmental disorders caused by mutations in MECP2 and FMR1 genes, respectively, show concurrent symptoms of ASD (25\%-100\%) [16]. Conversely, the occurrence of RTT and FXS is seen in $0.5 \%-2 \%$ of ASD patients. The patients with tuberous sclerosis have an ASD with a high rate (20\%) of co-occurrence [16]. Tuberous sclerosis is caused by TSC1 or TSC2 mutations that affect a diversity of signaling pathways that overlap those related to the ASDs. It is also estimated that about $40 \%$ of ID patients have an ASD [17]. Recent genetic studies of ID cases suggest that CNV is associated with ID and congenital anomalies. Although it is clear that ASD is classified as a congenital genetic disorder, it is possible that, alternatively, gene expression changes occur not only congenitally but also throughout life after birth by epigenetic modification. Aberrant epigenetic modifications are involved in several neurodevelopmental disorders. Rett syndrome, Rubinstein-Taybi Syndrome (RTS) and Coffin-Lowry Syndrome (CLS) are caused by the gene mutation associated with dysfunction of a protein binding to methylated cytosine, a histone acetyltransferase, and a histone phosphorylase, respectively [18]. These dysfunctions affect epigenetic status and cause downstream changes in susceptive gene expressions, resulting in neurodevelopmental disorders. These disorders can be caused by epigenetic alteration of susceptible gene expression. The concept may be also applied to ASD. Besides genetic abnormality, other external factors such as environment, virus infection, and drug administration are considered to be risk factors of ASD (Figure 2). Due to unknown etiology in more than half of ASD, it is considered that the external factors can increase risk of ASD in addition to genetic variations, possi-

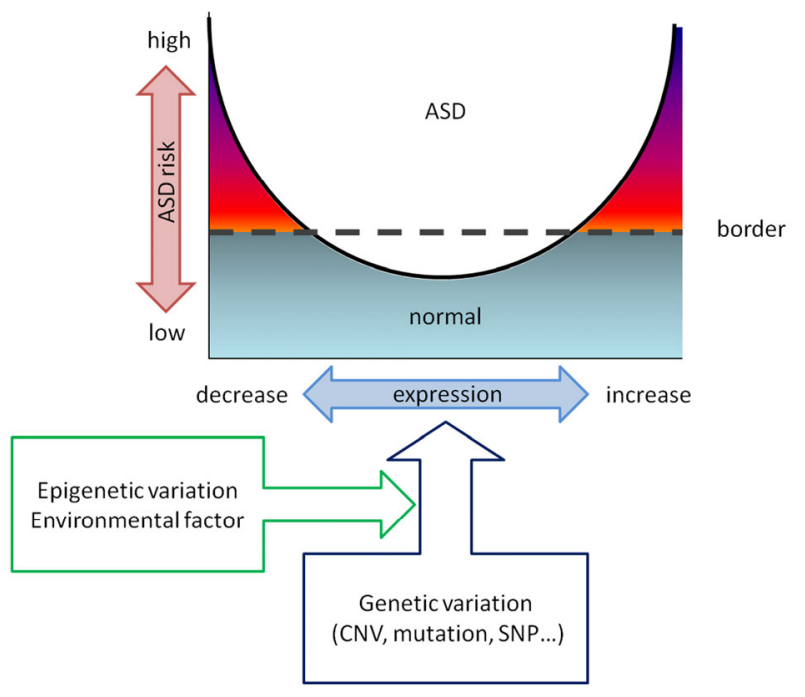

Figure 2 A conceptual model of the relation between susceptive gene expression and ASD risk. Genetic abnormality is the starting point of ASD risk. In addition, external factors such as environment, viral infection, and drug administration can coordinately affect the gene expression. The susceptibility to ASD is influenced by the aberrant gene expression relative to neuronal function. SNP, single nucleotide polymorphism.

bly through changes in epigenetic status that the external factors can cause.

\section{Copy number variation $(\mathrm{CNV})$}

$\mathrm{CNV}$ is a large nucleotide change ( $1 \mathrm{~kb}$ to a few $\mathrm{Mb}$ ) in chromosomal complement and the changes occur by inheritance or de novo mutation. De novo $\mathrm{CNV}$ occurs in offspring whose parents have no $\mathrm{CNV}$ and emerges with a 
higher frequency compared to the inherited case. $\mathrm{CNV}$ is found in about $1 \%$ of general population but in most of the cases, it is not recognized as a cause of disease [12]. It is reasonable to suppose that the $\mathrm{CNV}$ s in general population do not have a large disease risk because the regions affected are non-susceptible. In the ASD case, however, genetic variation seems to be localized in the genomic region that is susceptible to disorders. About $20 \%$ of ASD patients have one or a few CNVs throughout the whole genomic region (Figure 1). The CNV database has been under construction by scientists in cooperation with non-profit foundations (for example, Simons Foundation and Autism Speaks). Many genes are contained in the $\mathrm{CNV}$ chromosomal region. The gene expression is increased in duplication cases and decreased in deletion cases, which means that the gene dosage can influence risk and susceptibility of ASD. The CNVs have some commonality in chromosomal regions. Thus, the specific genetic difference is likely to be involved with pathogenesis of ASD. For example, 15q11-13 duplication and 16p11.2 deletion/duplication are the most frequent cases found in ASD [2,13,19]. Recently, molecular network analysis suggested that the genes included in CNV regions are highly associated with neuronal functional processes (e.g. ubiquitination, neuronal cell-adhesion, synaptogenesis, axon guidance and dendrite morphogenesis) [3,5,7]. Moreover, transcriptomic analysis with the post-mortem brain implicated transcriptional and splicing dysregulation of mRNAs as underlying mechanisms of neuronal dysfunction in ASD [20]. There can be convergent pathways to neuronal function in ASD that exhibit autistic phenotype. Incidentally, the 4:1 male to female ratio in ASD suggests that penetrance is lower in females than in males. Gilman et al. [3] reported interesting results that CNVs in females are significantly larger than in males and genes affected by de novo CNVs in females are more functionally important for identified gene networks in ASD. The resistance to genetic perturbation in females is unlikely to be same in males. Given the increasing trend of the CNV studies, $\mathrm{CNV}$ will be more frequently found in ASD and other disorders. Although CNVs have large variations and the effect of CNV is yet poorly understood, there is no doubt that the CNVs including susceptive genes are associated with ASD pathogenesis.

\section{Epigenetic alterations in ASD}

$\mathrm{CNV}$ influences the dosage imbalance of autism susceptive genes. Gene expression changes without genetic alterations, known as epigenetics, are also crucial mechanisms leading to ASDs. Recent evidence supports that alterations in epigenetics are involved in ASDs. RTT and FXS, neurodevelopmental disorders associated with ASDs, are related to epigenetic dysregulation [21,22]. Furthermore, a number of chromosomal loci that have linkage in ASDs are subjected to genomic imprinting, suggesting association of epigenetic factors increases the risk of ASDs [23]. In addition, global epigenetic analysis in lymphoblastoid cell lines obtained from monozygotic twins discordant for diagnosis of ASD suggested widespread epigenetic abnormality in patients with ASD [24]. ASD associated genes are decreased by increased promoter methylation in ASD brain samples as well as peripheral ones [25,26]. As above, epigenetics is accountable for heterogeneity of autism. Epigenetic modification in the brain plays an important role in individual behavior, learning and memory formation [27-29]. Recently, it is suggested that parental environment can affect epigenetic modification of their children $[30,31]$.

\section{DNA methylation and the associated disorder}

In vertebrates, the $5^{\prime}$ position of cytosine residue in cytosine-guanine $(\mathrm{CpG})$ dinucleotides is predominantly methylated [32]. Local methylation of cytosine in the region where CpGs appear frequently, called the $\mathrm{CpG}$ island, around transcription start site is closely related to gene repression. 5-methylcytosine $(5 \mathrm{mC})$ is the most widely studied DNA modification that is important for genomic imprinting and $\mathrm{X}$ chromosome inactivation by induction of heterochromatinization. DNA methylation is regulated in developmental and tissue-specific manners by de novo methyltransferase 1 (DNMT1) and DNMT3s. Demethylation mechanisms have been rapidly understood in the past few years since 5-hydroxymethylation of cytosine $(5 \mathrm{hmC})$ was reported in the mammalian brain [33,34]. Ten-eleven-translocation genes (TETS) have important functions in hydroxylation, formylation and carboxylation of $5 \mathrm{mC}$, following base excision repair to unmodified cytosine [35,36]. Global $5 \mathrm{mC}$ and $5 \mathrm{hmC}$ analyses suggested that $5 \mathrm{hmC}$ is associated with active gene state and involved in development and aging in the mammalian brain. DNA methylation is recognized by a family of DNA-binding proteins with methyl-CpG binding domains (MBDs), known as the MBD protein family. These proteins bind to $5 \mathrm{mC}$ that interacts with many components and usually act as transcriptional repressors. RTT is caused by mutation of methyl-CpG binding protein 2 (MeCP2) [37]. $\mathrm{MeCP} 2$ is a nuclear protein that attaches to methylated DNA and regulates gene expression by inhibiting or recruiting transcription factors. Loss or mutation of MeCP2 causes transcriptional deregulation and also leads to ASD phenotypes. All individuals with RTT have an ASD. FXS is the most common inherited cause of ID. Patients with FXS have a characteristic physical appearance and impaired behavior with co-occurrence of ASD in $25 \%$ of male and $6 \%$ of female patients [38]. FXS arises from extremely expanded CGG triplet repeats localized at the promoter of the FMRI gene which codes the Fragile $\mathrm{X}$ mental retardation 
protein (FMRP). Inheritance of unstable allele causes expansion of the normal number of repeats (6-40). The expanded allele increases instability and develops into pre-mutation (50-200) by inheritance, followed by fullmutation (200 ) in a generation. The full mutation state results in hypermethylation of the promoter region of the FMRI gene and prevents gene expression. The detailed mechanistic consequences of CGG repeat expansion and methylation are unclear. FMRP is involved in diverse biological processes including signal transduction, RNA processing, and transcription. Loss of function of FMRP is linked to ASD phenotypes. Recently, a microdeletion that includes a single gene for methyl-CpG-binding domain 5 (MBD5) was found in ASD patients [39]. MBD5 associates with heterochromatin but does not directly bind to methylated DNA [40]. MBD5 is likely to interact with myocyte enhancer-binding factor $2 \mathrm{C}$, a gene known to regulate expression of neuronal genes and is associated with ASD [41,42]. The altered gene dosage such as in MBD5 provides additional support for importance of DNA methylation in ASD.

\section{SNV and CNV relative to histone modifica- tion}

Histone modification is another important mechanism of epigenetic modification. Acetylation and methylation of lysine residues in the histone $\mathrm{H} 3$ subunit are currently subject to considerable research as the processes mediate gene activation and silencing. Acetylation is regulated by histone acetyltransferases (HATs) and histone deacetylases (HDACs). Methylation of histone is also explained by histone lysine methyltransferases and demethylases as recently identified. Histone modification is involved in dynamic cellular functions such as stress response, signal induction, and responses to an environmental change [43]. There are syndromes considered specifically as epigenetic disorders. RTS, characterized by short stature, learning difficulties, and distinctive facial features, is caused by mutations in the cAMP (cyclic adenosine monophosphate) response element-binding protein gene $(C R E B B P)$ [44]. The protein CREBBP recruits other transcription factors and has HAT activity. The mutation of $C R E B B P$ has potential to affect regulation of other genes, but the underlying mechanism connecting this epigenetic regulation to brain development is still unknown. CLS, which shows severe ID with abnormalities of growth, cardio-vascular system, and kyphoscoliosis, is caused by loss-of-function mutations in the RSK2 gene [45]. RSK2 is a growth factor-regulated serine- threonine protein kinase that acts in the ras-mitogen-activated protein kinase signaling pathway. RSK2 affects chromatin structure through direct phosphorylation of histones. Deletion of the epigenetic modification enzyme is possibly causative for autism. Recently, a mouse model for 9q34 sub- telomeric deletion syndrome was generated [46]. This disorder is characterized by severe ID, developmental delay, facial dysmorphism, and autistic behavior caused by euchromatin histone methyltransferase 1 (EHMT1) gene haplo-insufficiency [47]. EMHT1 is associated with methylation of the 9th lysine of histone H3 (H3K9), which causes transcriptional repression. Mice with heterozygous deletion of Ehmtl exhibit hypoactivity and the autistic-like behavior [46]. The abnormal histone modification can influence the occurrence and severity of neurodevelopmental disorders.

\section{Prenatal stress from environmental factors}

Epigenetic markers are dynamically changed during gynogenesis, embryogenesis, differentiation, and development under rigorous controls. Flexibility of epigenetic modifications indicates that these epigenetic signatures can be destabilized by environmental agents. Parental conditions (e.g. age and psychiatric history) and environmental factors (e.g. chemical exposure and maternal infection) at prenatal stage can become risk factors in neurodevelopmental disorders $[48,49]$. It is possible that these risk factors affect regulation of epigenetic modulator and alter expression of genes that are responsible for brain functions. Valproic acid (VPA) has been used for treatment of depression, schizophrenia, and bipolar disease [50,51]. Although the mechanism is not fully understood, VPA is implicated to act as an inhibitor for class I and class IIb HDACs [52]. Given that global gene expression is affected by histone modification, the effect of VPA can be related to abnormal neuronal activity in human brain. Furthermore, prenatal exposure to VPA is clinically linked to ASD [53]. Children with fetal valproate syndrome show phenotypic facial abnormalities, developmental disabilities, and, occasionally, major organ abnormalities and autism. Rodents prenatally exposed to VPA are used as an autism model. The fact that mice transiently given VPA at E12.5, but not at E9 and E14.5, showed autism-like behavior at 8 weeks of age [54], suggests hyperacetylation of histone at a critical period plays a key role in cortical pathology and generation of autism-like behavior. Moreover, prenatal stress exposure triggers epigenetic variations. Male offspring, but not female, exposed to prenatal stress in early gestation results in maladaptive behavior to stress response, which suggests that sex specific placental response underlies male vulnerability to autism [55]. There are certainly epigenetic sex differences in the brain [56] and it can also link to the different sensitivity between male and female in ASD. Psychological stress during pregnancy has also been recognized as a possible risk factor of autism [57,58]. Further investigations are necessary to understand the relationship of autistic phenotype and DNA/chromatin modification in the brain during embryogenesis. 


\section{Generation of model mice}

It is generally known that Mus musculus is a social species with high levels of reciprocal social interactions. At the same time, the genetic engineering in mice is well established. Therefore, it is possible to generate ASD model mice with the genetic variation found in ASD. The usefulness of the model mouse requires certain criteria. First, the model mice should have "construct validity". The construct validity means that the model mice have the same genomic dysfunction found in ASD patients. Unfortunately, it is difficult to generate the model mice for epigenetic alteration because of the aspect of construct validity. As noted above, a number of SNVs known for ASD (NLGN3, NLGN4, NRXN1, CNTNAP2 and SHANK3) are used to create model [59-64]. In a similar approach, model mice for RTT and FXS are also generated and analyzed [65-69]. However, given recent findings, it is important to validate whether human CNV found in ASD affects autistic phenotypes or not [70]. We and other two groups reported that the model mice with human CNVs (chromosome 15q11-13, 16p11.2 and 22q11) show abnormal behavior and organic aberration of brain seen in ASD and schizophrenia [71-73]. These groups used chromosomal engineering established by Alan Bradley and colleagues [74,75]. To briefly describe the methods to construct model mice for $\mathrm{CNV}$, two loxP sites are inserted into two homologous chromosomes at each end of $\mathrm{CNV}$ in mouse embryonic stem (ES) cell. Using Cre recombinase, the chromosomes are recombined at the loxP sites and either the duplication or the deletion type can be constructed. The ES cells with recombined chromosomes are implanted to blastocysts and the chimera mice with $\mathrm{CNV}$ are generated.

\section{Phenotypic assay}

\subsection{Behavioral test}

The model mice should be checked by behavioral assays since ASD is diagnosed by behavioral phenotypes [76]. First, the mice are subjected to physical exam. If they have physical abnormality (i.e. blind eye, deafness, or ambulation difficulty), they must be considered improper for behavioral assays described below. It is necessary to know the mice have normal sensibility before they are subjected to social behavior tests. The olfactory test should be done with natural smells. It is critical to check if the mice can detect natural smells. The difficulty in olfaction affects social tests in mice because they mainly use olfactory function to understand individuals and the environment of the area they are in. After normal physical and perceptive conditions are confirmed, the model mice are subjected to social behavior test and/or other tests of concern. ASD models should have "face validity". The face validity means that the model mice show the abnormal behaviors seen in ASD patients. Main phenotypes are deficit in social interaction, impaired com- munication, and repetitive behavior or restricted interest. The model mice described above exhibited such behavioral deficits [59-65,68,69,71-73]. The three-chamber test (or one chamber test) is used to check social interaction. The ultrasonic vocalization is used to check communication skills at young stages. The reversal learning test using Morris water maze or Barnes maze checks for behavioral inflexibility. Other behavioral tests are also performed to understand the face validity of the model mice (i.e. open field test and fear conditioning test for anxiety and context memory, home cage activity, circadian rhythm, and nurturing behavior).

\subsection{Pathomorphology}

Morphological research has found increased brain size in ASD patients at younger stage compared with age-matched controls [77]. MRI system is useful to measure the brain size of the model mice. It can be relevant to know the correlation of $\mathrm{CNV}$ and brain size throughout developmental stages in ASD subjects. The model mice with 16p11.2 deletion exhibit the significant increase of regional brain sizes but duplication mice, oppositely, exhibit a smaller tendency compared with wild type mice, suggesting that dosage of 16 p11.2 affects brain architecture [72]. The structures of mini-column in cortical region are also abnormal in ASD patients whose structures are reported to be small [78]. It is considered that the column difference is the origin of dysfunction in the regulation of sensory inputs and/or outputs. It is necessary to check model mice for the morphological abnormality using imaging tools. Given that recent molecular network analysis of CNV implied the dysfunction of neuronal cell-adhesion, synaptogenesis, axon guidance and dendrite morphogenesis, the pathomorphological aspects should not be ignored in studying the model mice [79]. In the model mice for ASD, Nlgn3, Shank3 and MeCP2 mutant mice exhibit significant differences in spine density and dendrite length, suggesting the abnormalities in synaptic function and neurite growth may be a common dysfunction of ASD [63,69,80].

\subsection{Pathophysiology}

There is a hypothesis that dysfunction of excitatory and inhibitory balance causes psychiatric disorders including ASD [81]. About 30\% ASD patients have epilepsy and decreased GAD65/67 mRNA levels, as reported in several examples [82,83]. Moreover, many ASD model mice show excitatory/inhibitory (E/I) imbalance [61-65,84,85]. One method to verify this hypothesis is to perform immunohistochemistry analysis with the markers of excitatory and inhibitory neurons; for example, ratio of markers for vesicular glutamate transporter (VGluT1,2,3) over vesicular GABA transporter (VGAT) would indicate the E/I balance among neuronal populations. Data from optogenetic ex- 
periments suggest that the social phenotypes can be affected by the imbalance of E/I ratio in the prefrontal region but not in the visual region in the cortex [84]. The immunohistochemistry methods can be applied to measure the E/I ratio in the whole brain. If measurements of E/I markers suggest for imbalance, electrophysiological measurements should be employed to establish the functional E/I ratio. We suspect this approach can provide a viable means of elucidating neuron type-specific defects leading to autism. Ube3a knockout mice, the Angelman syndrome model, show an $\mathrm{E} / \mathrm{I}$ imbalance and the dysfunction depends on inhibitory neuronal defects [87]. Interestingly, loss of $\mathrm{MeCP} 2$ in GABAergic neurons is more critical for social interaction than loss of the protein in catecholaminergic and serotonergic neurons $[65,88]$. These reports suggest that the deficits of sociability emerge as a consequence of abnormal function in specific types of neurons.

\subsection{Pathological endophenotype analysis}

The point of endophenotype analysis is to assess genetic basis of ASD pathologies. Many candidate genes and loci are considered to be involved with ASD pathogenesis. However, precise pathology remains unknown. Specifically, it is unclear how the genetic mutation or variation affects the behavior of ASD. There is a general hypothesis on the mechanism of ASD pathogenesis where heterogeneous candidate genes and loci are converging on a (or some) main dysfunction of the central nervous system [89]. There can be dysfunctions in neuronal cell activity, synaptogenesis, dendrite extension, and/or fine neuronal connection in the ASD brain. If any such dysfunction were found in model mice, it would provide the next step toward the rescue of the dysfunction which can be treatable with a therapeutic drug. Clinical researchers are also seeking a biomarker of ASD to establish objective diagnosis criteria of ASD. A biomarker is a characteristic that is objectively measured and evaluated as an indicator of normal biological processes, pathogenic processes, or pharmacological responses to a therapeutic intervention. Therefore, the possibility of convergence to endophenotype of ASD must be fully evaluated. However, there are many reports of biomarkers associated with ASD but the results are controversial [90]. Given the heterogeneity involved with the population of ASD patients, the inconsistencies are not surprising. The merit of using the model mice is to evaluate the effect of a single genetic cause. The model mice with 15q11-13 duplication have lower serotonin content in the brain compared with the wild type [91], suggesting that serotonergic dysfunction can cause behavioral abnormalities in ASD with 15q11-13 duplication. Some drug can be effective in the genetically specific ASD population but the effectiveness cannot be guaranteed in other populations. By using the model mice with specific genetic variation, the therapeutic effect of drugs can be better evaluated and understood.

\section{Conclusion}

It is difficult to completely explain why patients with ASD exhibit defects in social behavior because many factors can intricately participate in behavioral phenotypes. But now, we have a strong tool with model mice to investigate the influence of genetic variations found in ASD. It will be useful not only to understand ASD pathology but also to find therapeutically efficacious drugs. CNV and epigenetic variations will continue to be discovered in ASD and other neurodevelopmental disorders. We argue in this review that the altered dosage and dysfunction of susceptible genes based on genetic and/or epigenetic variations can be a cause of ASD. Considering more a few occurrences of CNVs in general population, we speculate that such genetic and epigenetic variations account for the wide personality spectrum outside the borders of ASD. Studying the influence of altered gene expression in a step-by-step way would be fruitful in this regard.

The authors acknowledge all members of Takumi laboratory. This work was supported in part by a grant from Japan Society for the Promotion of Science and Ministry of Education, Culture, Sports, Science and Technology KAKENHI, Core Research for Evolutional Science and Technology, Strategic International Cooperative Program of Japan Science and Technology Agency, and by research grants from Takeda Science Foundation, the Naito Foundation and Terumo Life Science Foundation.

1 Autism and Developmental Disabilities Monitoring Network Surveillance Year 2008 Principal Investigators; Centers for Disease Control and Prevention. Prevalence of autism spectrum disorders-Autism and Developmental Disabilities Monitoring Network, 14 sites, United States, 2008. MMWR Surveill Summ, 2012, 61: $1-19$

2 Levy D, Ronemus M, Yamrom B, Lee YH, Leotta A, Kendall J, Marks S, Lakshmi B, Pai D, Ye K, Buja A, Krieger A, Yoon S, Troge J, Rodgers L, Iossifov I, Wigler M. Rare de novo and transmitted copy-number variation in autistic spectrum disorders. Neuron, 2011, 70: 886-897

3 Gilman SR, Iossifov I, Levy D, Ronemus M, Wigler M, Vitkup D. Rare de novo variants associated with autism implicate a large functional network of genes involved in formation and function of synapses. Neuron, 2011, 70: 898-907

4 Iossifov I, Ronemus M, Levy D, Wang Z, Hakker I, Rosenbaum J, Yamrom B, Lee YH, Narzisi G, Leotta A, Kendall J, Grabowska E, Ma B, Marks S, Rodgers L, Stepansky A, Troge J, Andrews P, Bekritsky M, Pradhan K, Ghiban E, Kramer M, Parla J, Demeter R, Fulton LL, Fulton RS, Magrini VJ, Ye K, Darnell JC, Darnell RB, Mardis ER, Wilson RK, Schatz MC, McCombie WR, Wigler M. De novo gene disruptions in children on the autistic spectrum. Neuron, 2012, 74: 285-299

5 Glessner JT, Wang K, Cai G, Korvatska O, Kim CE, Wood S, Zhang $\mathrm{H}$, Estes A, Brune CW, Bradfield JP, Imielinski M, Frackelton EC, Reichert J, Crawford EL, Munson J, Sleiman PM, Chiavacci R, Annaiah K, Thomas K, Hou C, Glaberson W, Flory J, Otieno F, Garris M, Soorya L, Klei L, Piven J, Meyer KJ, Anagnostou E, Sakurai T, Game RM, Rudd DS, Zurawiecki D, McDougle CJ, Davis LK, Miller 
J, Posey DJ, Michaels S, Kolevzon A, Silverman JM, Bernier R, Levy SE, Schultz RT, Dawson G, Owley T, McMahon WM, Wassink TH, Sweeney JA, Nurnberger JI, Coon H, Sutcliffe JS, Minshew NJ, Grant SF, Bucan M, Cook EH, Buxbaum JD, Devlin B, Schellenberg GD, Hakonarson H. Autism genome-wide copy number variation reveals ubiquitin and neuronal genes. Nature, 2009, 459: 569-573

6 Neale BM, Kou Y, Liu L, Ma'ayan A, Samocha KE, Sabo A, Lin CF, Stevens C, Wang LS, Makarov V, Polak P, Yoon S, Maguire J, Crawford EL, Campbell NG, Geller ET, Valladares O, Schafer C, Liu H, Zhao T, Cai G, Lihm J, Dannenfelser R, Jabado O, Peralta Z, Nagaswamy U, Muzny D, Reid JG, Newsham I, Wu Y, Lewis L, Han Y, Voight BF, Lim E, Rossin E, Kirby A, Flannick J, Fromer M, Shakir K, Fennell T, Garimella K, Banks E, Poplin R, Gabriel S, DePristo M, Wimbish JR, Boone BE, Levy SE, Betancur C, Sunyaev S, Boerwinkle E, Buxbaum JD, Cook EH Jr, Devlin B, Gibbs RA, Roeder K, Schellenberg GD, Sutcliffe JS, Daly MJ. Patterns and rates of exonic de novo mutations in autism spectrum disorders. Nature, 2012, 485: 242-245

7 Pinto D, Pagnamenta AT, Klei L, Anney R, Merico D, Regan R, Conroy J, Magalhaes TR, Correia C, Abrahams BS, Almeida J, Bacchelli E, Bader GD, Bailey AJ, Baird G, Battaglia A, Berney T, Bolshakova N, Bölte S, Bolton PF, Bourgeron T, Brennan S, Brian J, Bryson SE, Carson AR, Casallo G, Casey J, Chung BH, Cochrane L, Corsello C, Crawford EL, Crossett A, Cytrynbaum C, Dawson G, de Jonge M, Delorme R, Drmic I, Duketis E, Duque F, Estes A, Farrar P, Fernandez BA, Folstein SE, Fombonne E, Freitag CM, Gilbert J, Gillberg C, Glessner JT, Goldberg J, Green A, Green J, Guter SJ, Hakonarson H, Heron EA, Hill M, Holt R, Howe JL, Hughes G, Hus V, Igliozzi R, Kim C, Klauck SM, Kolevzon A, Korvatska O, Kustanovich V, Lajonchere CM, Lamb JA, Laskawiec M, Leboyer M, Le Couteur A, Leventhal BL, Lionel AC, Liu XQ, Lord C, Lotspeich L, Lund SC, Maestrini E, Mahoney W, Mantoulan C, Marshall CR, McConachie H, McDougle CJ, McGrath J, McMahon WM, Merikangas A, Migita O, Minshew NJ, Mirza GK, Munson J, Nelson SF, Noakes C, Noor A, Nygren G, Oliveira G, Papanikolaou K, Parr JR, Parrini B, Paton T, Pickles A, Pilorge M, Piven J, Ponting CP, Posey DJ, Poustka A, Poustka F, Prasad A, Ragoussis J, Renshaw K, Rickaby J, Roberts W, Roeder K, Roge B, Rutter ML, Bierut LJ, Rice JP, Salt J, Sansom K, Sato D, Segurado R, Sequeira AF, Senman L, Shah N, Sheffield VC, Soorya L, Sousa I, Stein O, Sykes N, Stoppioni V, Strawbridge C, Tancredi R, Tansey K, Thiruvahindrapduram B, Thompson AP, Thomson S, Tryfon A, Tsiantis J, Van Engeland H, Vincent JB, Volkmar F, Wallace S, Wang K, Wang Z, Wassink TH, Webber C, Weksberg R, Wing K, Wittemeyer K, Wood S, Wu J, Yaspan BL, Zurawiecki D, Zwaigenbaum L, Buxbaum JD, Cantor RM, Cook EH, Coon H, Cuccaro ML, Devlin B, Ennis S, Gallagher L, Geschwind DH, Gill M, Haines JL, Hallmayer J, Miller J, Monaco AP, Nurnberger JI Jr, Paterson AD, Pericak-Vance MA, Schellenberg GD, Szatmari P, Vicente AM, Vieland VJ, Wijsman EM, Scherer SW, Sutcliffe JS, Betancur C. Functional impact of global rare copy number variation in autism spectrum disorders. Nature, 2010, 466: 368-372

8 O'Roak BJ, Deriziotis P, Lee C, Vives L, Schwartz JJ, Girirajan S, Karakoc E, Mackenzie AP, Ng SB, Baker C, Rieder MJ, Nickerson DA, Bernier R, Fisher SE, Shendure J, Eichler EE. Exome sequencing in sporadic autism spectrum disorders identifies severe de novo mutations. Nat Genet, 2011, 43: 585-589

9 O'Roak BJ, Vives L, Girirajan S, Karakoc E, Krumm N, Coe BP, Levy R, Ko A, Lee C, Smith JD, Turner EH, Stanaway IB, Vernot B, Malig M, Baker C, Reilly B, Akey JM, Borenstein E, Rieder MJ, Nickerson DA, Bernier R, Shendure J, Eichler EE. Sporadic autism exomes reveal a highly interconnected protein network of de novo mutations. Nature, 2012, 485: 246-250

10 Sanders SJ, Ercan-Sencicek AG, Hus V, Luo R, Murtha MT, Moreno-De-Luca D, Chu SH, Moreau MP, Gupta AR, Thomson SA, Mason CE, Bilguvar K, Celestino-Soper PB, Choi M, Crawford EL, Davis L, Wright NR, Dhodapkar RM, DiCola M, DiLullo NM, Fernandez TV, Fielding-Singh V, Fishman DO, Frahm S, Garagaloyan R, Goh GS, Kammela S, Klei L, Lowe JK, Lund SC, McGrew AD,
Meyer KA, Moffat WJ, Murdoch JD, O'Roak BJ, Ober GT, Pottenger RS, Raubeson MJ, Song Y, Wang Q, Yaspan BL, Yu TW, Yurkiewicz IR, Beaudet AL, Cantor RM, Curland M, Grice DE, Günel M, Lifton RP, Mane SM, Martin DM, Shaw CA, Sheldon M, Tischfield JA, Walsh CA, Morrow EM, Ledbetter DH, Fombonne E, Lord C, Martin CL, Brooks AI, Sutcliffe JS, Cook EH Jr, Geschwind D, Roeder K, Devlin B, State MW. Multiple recurrent de novo CNVs, including duplications of the 7q11.23 Williams syndrome region, are strongly associated with autism. Neuron, 2011, 70: 863-885

11 Sanders SJ, Murtha MT, Gupta AR, Murdoch JD, Raubeson MJ, Willsey AJ, Ercan-Sencicek AG, DiLullo NM, Parikshak NN, Stein JL, Walker MF, Ober GT, Teran NA, Song Y, El-Fishawy P, Murtha RC, Choi M, Overton JD, Bjornson RD, Carriero NJ, Meyer KA, Bilguvar K, Mane SM, Sestan N, Lifton RP, Günel M, Roeder K, Geschwind DH, Devlin B, State MW. De novo mutations revealed by whole-exome sequencing are strongly associated with autism. Nature, 2012, 485: 237-241

12 Sebat J, Lakshmi B, Malhotra D, Troge J, Lese-Martin C, Walsh T, Yamrom B, Yoon S, Krasnitz A, Kendall J, Leotta A, Pai D, Zhang R, Lee YH, Hicks J, Spence SJ, Lee AT, Puura K, Lehtimäki T, Ledbetter D, Gregersen PK, Bregman J, Sutcliffe JS, Jobanputra V, Chung W, Warburton D, King MC, Skuse D, Geschwind DH, Gilliam TC, Ye K, Wigler M. Strong association of de novo copy number mutations with autism. Science, 2007, 316: 445-449

13 Vorstman JA, Staal WG, van Daalen E, van Engeland H, Hochstenbach PF, Franke L. Identification of novel autism candidate regions through analysis of reported cytogenetic abnormalities associated with autism. Mol Psychiatry, 2006, 11: 1, 18-28

14 Weiss LA, Arking DE; Gene Discovery Project of Johns Hopkins \& the Autism Consortium, Daly MJ, Chakravarti A. A genome-wide linkage and association scan reveals novel loci for autism. Nature, 2009, 461: 802-808

15 Cooper GM, Coe BP, Girirajan S, Rosenfeld JA, Vu TH, Baker C, Williams C, Stalker H, Hamid R, Hannig V, Abdel-Hamid H, Bader P, McCracken E, Niyazov D, Leppig K, Thiese H, Hummel M, Alexander N, Gorski J, Kussmann J, Shashi V, Johnson K, Rehder C, Ballif BC, Shaffer LG, Eichler EE. A copy number variation morbidity map of developmental delay. Nat Genet, 2011, 43: 838-846

16 Abrahams BS, Geschwind DH. Advances in autism genetics: on the threshold of a new neurobiology. Nat Rev Genet, 2008, 9: 341-355

17 van Bokhoven H. Genetic and epigenetic networks in intellectual disabilities. Annu Rev Genet, 2011, 45: 81-104

18 Gropman AL, Batshaw ML. Epigenetics, copy number variation, and other molecular mechanisms underlying neurodevelopmental disabilities: new insights and diagnostic approaches. J Dev Behav Pediatr, 2010, 31: 582-591

19 Weiss LA, Shen Y, Korn JM, Arking DE, Miller DT, Fossdal R, Saemundsen E, Stefansson H, Ferreira MA, Green T, Platt OS, Ruderfer DM, Walsh CA, Altshuler D, Chakravarti A, Tanzi RE, Stefansson K, Santangelo SL, Gusella JF, Sklar P, Wu BL, Daly MJ; Autism Consortium. Association between microdeletion and microduplication at 16p11.2 and autism. N Engl J Med, 2008, 358: 667-675

20 Voineagu I, Wang X, Johnston P, Lowe JK, Tian Y, Horvath S, Mill $\mathrm{J}$, Cantor RM, Blencowe BJ, Geschwind DH. Transcriptomic analysis of autistic brain reveals convergent molecular pathology. Nature, 2011, 474: 380-384

21 Shahbazian MD, Zoghbi HY. Rett syndrome and MeCP2: linking epigenetics and neuronal function. Am J Hum Genet, 2002, 71: 1259-1272

22 Penagarikano O, Mulle JG, Warren ST. The pathophysiology of fragile X syndrome. Annu Rev Genomics Hum Genet, 2007, 8: 109-129

23 Schanen NC. Epigenetics of autism spectrum disorders. Hum Mol Genet, 2006, 15: R138-R150

24 Nguyen A, Rauch TA, Pfeifer GP, Hu VW. Global methylation profiling of lymphoblastoid cell lines reveals epigenetic contributions to autism spectrum disorders and a novel autism candidate gene, RORA, whose protein product is reduced in autistic brain. FASEB J, 2010, 24: 3036-3051 
25 Nagarajan RP, Hogart AR, Gwye Y, Martin MR, LaSalle JM. Reduced MeCP2 expression is frequent in autism frontal cortex and correlates with aberrant MECP2 promoter methylation. Epigenetics, 2006, 1: e1-e11

26 Gregory SG, Connelly JJ, Towers AJ, Johnson J, Biscocho D, Markunas CA, Lintas C, Abramson RK, Wright HH, Ellis P, Langford CF, Worley G, Delong GR, Murphy SK, Cuccaro ML, Persico A, Pericak-Vance MA. Genomic and epigenetic evidence for oxytocin receptor deficiency in autism. BMC Med, 2009, 7: 62

27 Sultan FA, Day JJ. Epigenetic mechanisms in memory and synaptic function. Epigenomics, 2011, 3: 157-181

28 Schaefer A, Sampath SC, Intrator A, Min A, Gertler TS, Surmeier DJ, Tarakhovsky A, Greengard P. Control of cognition and adaptive behavior by the GLP/G9a epigenetic suppressor complex. Neuron, 2009, 64: 678-691

29 Stefanko DP, Barrett RM, Ly AR, Reolon GK, Wood MA. Modulation of long-term memory for object recognition via HDAC inhibition. Proc Natl Acad Sci USA, 2009, 106: 9447-9452

30 James SJ, Melnyk S, Jernigan S, Pavliv O, Trusty T, Lehman S, Seidel L, Gaylor DW, Cleves MA. A functional polymorphism in the reduced folate carrier gene and DNA hypomethylation in mothers of children with autism. Am J Med Genet B Neuropsychiatr Genet, 2010, 153B: 1209-1220

31 Kappeler L, Meaney MJ. Epigenetics and parental effects. Bioessays, 2010, 32: 818-827

32 Bird A. DNA methylation patterns and epigenetic memory. Genes Dev, 2002, 16: 6-21

33 Tahiliani M, Koh KP, Shen Y, Pastor WA, Bandukwala H, Brudno Y, Agarwal S, Iyer LM, Liu DR, Aravind L, Rao A. Conversion of 5-methylcytosine to 5-hydroxymethylcytosine in mammalian DNA by MLL partner TET1. Science, 2009, 324: 930-935

34 Kriaucionis S, Heintz N. The nuclear DNA base 5-hydroxymethylcytosine is present in Purkinje neurons and the brain. Science, 2009, 324: 929-930

35 Ito S, Shen L, Dai Q, Wu SC, Collins LB, Swenberg JA, He C, Zhang Y. Tet proteins can convert 5-methylcytosine to 5-formylcytosine and 5-carboxylcytosine. Science, 2011, 333: 1300-1303

36 He YF, Li BZ, Li Z, Liu P, Wang Y, Tang Q, Ding J, Jia Y, Chen Z, Li L, Sun Y, Li X, Dai Q, Song CX, Zhang K, He C, Xu GL. Tet-mediated formation of 5-carboxylcytosine and its excision by TDG in mammalian DNA. Science, 2011, 333: 1303-1307

37 Amir RE, Van den Veyver IB, Wan M, Tran CQ, Francke U, Zoghbi HY. Rett syndrome is caused by mutations in X-linked MECP2, encoding methyl-CpG-binding protein 2. Nat Genet, 1999, 23: 185-188

38 Hatton DD, Sideris J, Skinner M, Mankowski J, Bailey DB Jr, Roberts J, Mirrett P. Autistic behavior in children with fragile X syndrome: prevalence, stability, and the impact of FMRP. Am J Med Genet A, 2006, 140A: 1804-1813

39 Talkowski ME, Mullegama SV, Rosenfeld JA, van Bon BW, Shen Y, Repnikova EA, Gastier-Foster J, Thrush DL, Kathiresan S, Ruderfer DM, Chiang C, Hanscom C, Ernst C, Lindgren AM, Morton CC, An Y, Astbury C, Brueton LA, Lichtenbelt KD, Ades LC, Fichera M, Romano C, Innis JW, Williams CA, Bartholomew D, Van Allen MI, Parikh A, Zhang L, Wu BL, Pyatt RE, Schwartz S, Shaffer LG, de Vries BB, Gusella JF, Elsea SH. Assessment of 2q23.1 microdeletion syndrome implicates MBD5 as a single causal locus of intellectual disability, epilepsy, and autism spectrum disorder. Am J Hum Genet, 2011, 89: 551-563

40 Laget S, Joulie M, Le Masson F, Sasai N, Christians E, Pradhan S, Roberts RJ, Defossez PA. The human proteins MBD5 and MBD6 associate with heterochromatin but they do not bind methylated DNA. PLoS One, 2010, 5: e11982

41 Toro R, Konyukh M, Delorme R, Leblond C, Chaste P, Fauchereau F, Coleman M, Leboyer M, Gillberg C, Bourgeron T. Key role for gene dosage and synaptic homeostasis in autism spectrum disorders. Trends Genet, 2010, 26: 363-372

42 Bandyopadhyay S, Chiang CY, Srivastava J, Gersten M, White S, Bell R, Kurschner C, Martin C, Smoot M, Sahasrabudhe S, Barber
DL, Chanda SK, Ideker T. A human MAP kinase interactome. Nat Methods, 2010, 7: 801-805

43 Allis CD, Jenuwein T, Reinberg D, Caparros ML. Epigenetics. Longlsland: Cold Spring Harbor Laboratory Press, 2007

44 Petrij F, Giles RH, Dauwerse HG, Saris JJ, Hennekam RC, Masuno M, Tommerup N, van Ommen GJ, Goodman RH, Peters DJ, Breuning $\mathrm{MH}$. Rubinstein-Taybi syndrome caused by mutations in the transcriptional co-activator CBP. Nature, 1995, 376: 348-351

45 Merienne K, Pannetier S, Harel-Bellan A, Sassone-Corsi P. Mitogen-regulated RSK2-CBP interaction controls their kinase and acetylase activities. Mol Cell Biol, 2001, 21: 7089-7096

46 Balemans MC, Huibers MM, Eikelenboom NW, Kuipers AJ, van Summeren RC, Pijpers MM, Tachibana M, Shinkai Y, van Bokhoven $\mathrm{H}$, Van der Zee CE. Reduced exploration, increased anxiety, and altered social behavior: Autistic-like features of euchromatin histone methyltransferase 1 heterozygous knockout mice. Behav Brain Res, 2010, 208: 47-55

47 Kleefstra T, Brunner HG, Amiel J, Oudakker AR, Nillesen WM, Magee A, Geneviève D, Cormier-Daire V, van Esch H, Fryns JP, Hamel BC, Sistermans EA, de Vries BB, van Bokhoven H. Loss-of-function mutations in euchromatin histone methyl transferase 1 (EHMT1) cause the 9q34 subtelomeric deletion syndrome. Am J Hum Genet, 2006, 79: 370-377

48 Baccarelli A, Bollati V. Epigenetics and environmental chemicals. Curr Opin Pediatr, 2009, 21: 243-251

49 Scherer SW, Dawson G. Risk factors for autism: translating genomic discoveries into diagnostics. Hum Genet, 2011, 130: 123-148

50 Sharma RP, Rosen C, Kartan S, Guidotti A, Costa E, Grayson DR, Chase K. Valproic acid and chromatin remodeling in schizophrenia and bipolar disorder: preliminary results from a clinical population. Schizophr Res, 2006, 88: 227-231

51 Machado-Vieira R, Ibrahim L, Zarate CA Jr. Histone deacetylases and mood disorders: epigenetic programming in gene-environment interactions. CNS Neurosci Ther, 2011, 17: 699-704

52 Monti B, Polazzi E, Contestabile A. Biochemical, molecular and epigenetic mechanisms of valproic acid neuroprotection. Curr Mol Pharmacol, 2009, 2: 95-109

53 Williams G, King J, Cunningham M, Stephan M, Kerr B, Hersh JH. Fetal valproate syndrome and autism: additional evidence of an association. Dev Med Child Neurol, 2001, 43: 202-206

54 Kataoka S, Takuma K, Hara Y, Maeda Y, Ago Y, Matsuda T. Autism-like behaviours with transient histone hyperacetylation in mice treated prenatally with valproic acid. Int J Neuropsychopharmacol, 2013, 16: 91-103

55 Mueller BR, Bale TL. Sex-specific programming of offspring emotionality after stress early in pregnancy. J Neurosci, 2008, 28: 9055-9065

56 McCarthy MM, Auger AP, Bale TL, De Vries GJ, Dunn GA, Forger NG, Murray EK, Nugent BM, Schwarz JM, Wilson ME. The epigenetics of sex differences in the brain. J Neurosci, 2009, 29: 12815-12823

57 Beversdorf DQ, Manning SE, Hillier A, Anderson SL, Nordgren RE, Walters SE, Nagaraja HN, Cooley WC, Gaelic SE, Bauman ML. Timing of prenatal stressors and autism. J Autism Dev Disord, 2005, 35: $471-478$

58 Ward AJ. A comparison and analysis of the presence of family problems during pregnancy of mothers of "autistic" children and mothers of normal children. Child Psychiatry Hum Dev, 1990, 20: 279-288

59 Etherton MR, Blaiss CA, Powell CM, Südhof TC. Mouse neurexin-1alpha deletion causes correlated electrophysiological and behavioral changes consistent with cognitive impairments. Proc Natl Acad Sci USA, 2009, 106: 17998-18003

60 Jamain S, Radyushkin K, Hammerschmidt K, Granon S, Boretius S, Varoqueaux F, Ramanantsoa N, Gallego J, Ronnenberg A, Winter D, Frahm J, Fischer J, Bourgeron T, Ehrenreich H, Brose N. Reduced social interaction and ultrasonic communication in a mouse model of monogenic heritable autism. Proc Natl Acad Sci USA, 2008, 105: 1710-1715

61 Bangash MA, Park JM, Melnikova T, Wang D, Jeon SK, Lee D, Sy- 
eda S, Kim J, Kouser M, Schwartz J, Cui Y, Zhao X, Speed HE, Kee SE, Tu JC, Hu JH, Petralia RS, Linden DJ, Powell CM, Savonenko A, Xiao B, Worley PF. Enhanced polyubiquitination of Shank3 and NMDA receptor in a mouse model of autism. Cell, 2011, 145: 758-772

62 Tabuchi K, Blundell J, Etherton MR, Hammer RE, Liu X, Powell CM, Südhof TC. A neuroligin-3 mutation implicated in autism increases inhibitory synaptic transmission in mice. Science, 2007, 318: 71-76

63 Peca J, Feliciano C, Ting JT, Wang W, Wells MF, Venkatraman TN, Lascola CD, Fu Z, Feng G. Shank3 mutant mice display autistic-like behaviours and striatal dysfunction. Nature, 2011, 472: 437-442

64 Penagarikano O, Abrahams BS, Herman EI, Winden KD, Gdalyahu A, Dong H, Sonnenblick LI, Gruver R, Almajano J, Bragin A, Golshani P, Trachtenberg JT, Peles E, Geschwind DH. Absence of CNTNAP2 leads to epilepsy, neuronal migration abnormalities, and core autism-related deficits. Cell, 2011, 147: 235-246

65 Chao HT, Chen H, Samaco RC, Xue M, Chahrour M, Yoo J, Neul JL, Gong S, Lu HC, Heintz N, Ekker M, Rubenstein JL, Noebels JL, Rosenmund C, Zoghbi HY. Dysfunction in GABA signalling mediates autism-like stereotypies and Rett syndrome phenotypes. Nature, 2010, 468: 263-269

66 Guy J, Hendrich B, Holmes M, Martin JE, Bird A. A mouse Mecp2-null mutation causes neurological symptoms that mimic Rett syndrome. Nat Genet, 2001, 27: 322-326

67 The Dutch-Belgian Fragile X Consortium. Fmrl knockout mice: a model to study fragile X mental retardation. Cell, 1994, 78: 23-33

68 Spencer CM, Alekseyenko O, Serysheva E, Yuva-Paylor LA, Paylor R. Altered anxiety-related and social behaviors in the Fmrl knockout mouse model of fragile X syndrome. Genes Brain Behav, 2005, 4: $420-430$

69 Cohen S, Gabel HW, Hemberg M, Hutchinson AN, Sadacca LA, Ebert DH, Harmin DA, Greenberg RS, Verdine VK, Zhou Z, Wetsel WC, West AE, Greenberg ME. Genome-wide activity-dependent MeCP2 phosphorylation regulates nervous system development and function. Neuron, 2011, 72: 72-85

70 Beckmann JS, Estivill X, Antonarakis SE. Copy number variants and genetic traits: closer to the resolution of phenotypic to genotypic variability. Nat Rev Genet, 2007, 8: 639-646

71 Nakatani J, Tamada K, Hatanaka F, Hutchinson AN, Sadacca LA, Ebert DH, Harmin DA, Greenberg RS, Verdine VK, Zhou Z, Wetsel WC, West AE, Greenberg ME. Abnormal behavior in a chromosome-engineered mouse model for human 15q11-13 duplication seen in autism. Cell, 2009, 137: 1235-1246

72 Horev G, Ellegood J, Lerch JP, Son YE, Muthuswamy L, Vogel H, Krieger AM, Buja A, Henkelman RM, Wigler M, Mills AA. Dosage-dependent phenotypes in models of 16p11.2 lesions found in autism. Proc Natl Acad Sci USA, 2011, 108: 17076-17081

73 Stark KL, Xu B, Bagchi A, Lai WS, Liu H, Hsu R, Wan X, Pavlidis P, Mills AA, Karayiorgou M, Gogos JA. Altered brain microRNA biogenesis contributes to phenotypic deficits in a 22q11-deletion mouse model. Nat Genet, 2008, 40: 751-760

74 van der Weyden L, Bradley A. Mouse chromosome engineering for modeling human disease. Annu Rev Genomics Hum Genet, 2006, 7 : 247-276

75 Yu Y, Bradley A. Engineering chromosomal rearrangements in mice. Nat Rev Genet, 2001, 2: 780-790
76 Silverman JL, Yang M, Lord C, Crawley JN. Behavioural phenotyping assays for mouse models of autism. Nat Rev Neurosci, 2010, 11: 490-502

77 Kemper TL, Bauman ML. Neuropathology of infantile autism. Mol Psychiatry, 2002, 7 Suppl 2: S12-S13

78 Bauman ML, Kemper TL. Neuroanatomic observations of the brain in autism: a review and future directions. Int J Dev Neurosci, 2005, 23: $183-187$

79 Penzes P, Cahill ME, Jones KA, VanLeeuwen JE, Woolfrey KM. Dendritic spine pathology in neuropsychiatric disorders. Nat Neurosci, 2011, 14: 285-293

80 Etherton M, Foldy C, Sharma M, Tabuchi K, Liu X, Shamloo M, Malenka RC, Südhof TC. Autism-linked neuroligin-3 R451C mutation differentially alters hippocampal and cortical synaptic function. Proc Natl Acad Sci USA, 2011, 108: 13764-13769

81 Rubenstein JL, Merzenich MM. Model of autism: increased ratio of excitation/inhibition in key neural systems. Genes Brain Behav, 2003, 2: $255-267$

82 Spence SJ, Schneider MT. The role of epilepsy and epileptiform EEGs in autism spectrum disorders. Pediatr Res, 2009, 65: 599-606

83 Fatemi SH, Halt AR, Stary JM, Kanodia R, Schulz SC, Realmuto GR. Glutamic acid decarboxylase 65 and $67 \mathrm{kDa}$ proteins are reduced in autistic parietal and cerebellar cortices. Biol Psychiatry, 2002, 52: 805-810

84 Dani VS, Chang Q, Maffei A, Turrigiano GG, Jaenisch R, Nelson SB. Reduced cortical activity due to a shift in the balance between excitation and inhibition in a mouse model of Rett syndrome. Proc Natl Acad Sci USA, 2005, 102: 12560-12565

85 Gibson JR, Bartley AF, Hays SA, Huber KM. Imbalance of neocortical excitation and inhibition and altered UP states reflect network hyperexcitability in the mouse model of fragile X syndrome. J Neurophysiol, 2008, 100: 2615-2626

86 Yizhar O, Fenno LE, Prigge M, Schneider F, Davidson TJ, O’Shea DJ, Sohal VS, Goshen I, Finkelstein J, Paz JT, Stehfest K, Fudim R, Ramakrishnan C, Huguenard JR, Hegemann P, Deisseroth K. Neocortical excitation/inhibition balance in information processing and social dysfunction. Nature, 2011, 477: 171-178

87 Wallace ML, Burette AC, Weinberg RJ, Philpot BD. Maternal loss of Ube3a produces an excitatory/inhibitory imbalance through neuron type-specific synaptic defects. Neuron, 2012, 74: 793-800

88 Samaco RC, Mandel-Brehm C, Chao HT, Ward CS, Fyffe-Maricich SL, Ren J, Hyland K, Thaller C, Maricich SM, Humphreys P, Greer JJ, Percy A, Glaze DG, Zoghbi HY, Neul JL. Loss of MeCP2 in aminergic neurons causes cell-autonomous defects in neurotransmitter synthesis and specific behavioral abnormalities. Proc Natl Acad Sci USA, 2009, 106: 21966-21971

89 Bill BR, Geschwind DH. Genetic advances in autism: heterogeneity and convergence on shared pathways. Curr Opin Genet Dev, 2009, 19: 271-278

90 Lam KS, Aman MG, Arnold LE. Neurochemical correlates of autistic disorder: a review of the literature. Res Dev Disabil, 2006, 27: 254-289

91 Tamada K, Tomonaga S, Hatanaka F, Nakai N, Takao K, Miyakawa T, Nakatani J, Takumi T. Decreased exploratory activity in a mouse model of $15 \mathrm{q}$ duplication syndrome; implications for disturbance of serotonin signaling. PLoS One, 2010, 5: e15126

Open Access This article is distributed under the terms of the Creative Commons Attribution License which permits any use, distribution, and reproduction in any medium, provided the original author(s) and source are credited. 